\title{
Macrophomina Crown and Root Rot of Pistachio in California
}

\author{
Mohamed T. Nouri 1,2 , Daniel P. Lawrence ${ }^{2}$, Craig E. Kallsen ${ }^{3}$ and Florent P. Trouillas ${ }^{1,2, *}$ \\ 1 Kearney Agricultural Research and Extension Center, Parlier, CA 93648, USA; mnouri@ucanr.edu \\ 2 Department of Plant Pathology, University of California, Davis, CA 95616, USA; dlawrence@ucdavis.edu \\ 3 University of California Cooperative Extension Kern County, Bakersfield, CA 93307, USA; \\ cekallsen@ucanr.edu \\ * Correspondence: flotrouillas@ucdavis.edu; Tel.: +1-559-646-6566
}

Received: 3 January 2020; Accepted: 20 January 2020; Published: 21 January 2020

check for updates

\begin{abstract}
In this study, declining pistachio rootstocks were detected in newly planted commercial pistachio orchards in Kern County, California. Symptoms were characterized by wilted foliage combined with crown rot in the rootstock. From diseased trees, 42 isolates were obtained, and all had similar cultural and morphological characteristics of Macrophomina phaseolina. Analyses of nucleotide sequences of three gene fragments, the internal transcribed spacer region (ITS1-5.8S-ITS2), partial sequences of $\beta$-tubulin, and translation elongation factor 1- $\alpha$ (TEF1) confirmed this identification, and 20 representative isolates are presented in the phylogenetic study. Testing of Koch's postulates showed that M. phaseolina, when inoculated to stems and roots of the pistachio rootstocks using mycelial plugs or a microsclerotial suspension, is indeed pathogenic to this host. The widely used clonal University of California Berkeley I (UCBI) rootstock appeared highly susceptible to M. phaseolina, suggesting that this pathogen is an emerging threat to the production of pistachio in California. This study confirmed the association of M. phaseolina with the decline of pistachio trees and represents the first description of this fungus as a crown rot-causing agent of pistachio in California.
\end{abstract}

Keywords: pistachio; crown rot; root rot; Macrophomina phaseolina; pathogenicity

\section{Introduction}

Pistachio (Pistacia vera L.) is one of California's many important, high-value nut crops. In 2017, California accounted for more than $99.1 \%$ of the United States pistachio crop, with approximately 101,327 hectares of bearing trees with a value of approximately $\$ 3.6$ billion (http://www.acpistachios.org). Although pistachio cultivation in California is relatively new, this industry has had a record of steady expansion. As pistachio demand and acreage continues to grow, fungal pathogens pose a continually evolving challenge for the industry.

Panicle and shoot blight of pistachio has been one of the main fungal diseases affecting pistachio in California, with early reports dating back to the 1980s [1]. In California, at least eight species of Botryosphaeriaceae fungi have been associated with this disease. Botrytis blossom and shoot blight caused by Botrytis cinerea Pers. [2] and Alternaria late blight caused by multiple species of Alternaria Nees [3] are additional important diseases of pistachio in California. Management of these various diseases has mainly relied upon the use of synthetic fungicides. Additional above-ground disease of pistachio includes Cytospora canker caused by several Cytospora spp. and Botryosphaeria canker caused by Neofusicoccum mediterraneum Crous, M.J. Wingf. and A.J.L. Phillips [4,5].

Verticillium wilt caused by Verticillium dahliae Kleb. has been the most important soil-borne disease affecting pistachio trees in California [6]. Verticillium dahliae is found worldwide in all types of soils and has an extremely wide host range, affecting more than 400 different plant species, including 
vegetables, flowers, fruit crops, ornamentals, and perennial agronomic crops [7-9]. Verticillium wilt of pistachio mostly occurred in orchards planted after crops such as cotton and tomato, which are highly susceptible to $V$. dahliae, or in orchards established adjacent to fields with susceptible crops [10]. The fungus can survive in the soil for many years due to extremely persistent resting structures, the microsclerotia. Accordingly, control of Verticillium wilt begins before the trees are planted and the site location is an important consideration. Former cotton, tomato, and alfalfa fields should be avoided, as they increase the risk of Verticillium wilt. The most effective control measures to combat Verticillium wilt is the use of resistant rootstocks. In California, commercial pistachio nut production began in the 1970s with Pistacia atlantica Desf. as the main pistachio rootstock [11]. However, P. atlantica is highly susceptible to infection by $V$. dahliae, and the fungus is widespread in soils of the San Joaquin Valley. The development and widespread planting of resistant University of California Berkeley I (UCBI) rootstocks has diminished the Verticillium wilt problem of pistachio in California. Symptoms of Verticillium wilt are now only observed sporadically in the southern half of the San Joaquin Valley, where the P. atlantica rootstock was initially planted.

California pistachio is also subject to root and crown rots caused by oomycetes such as Phytophthora and Phytopythium [12-14]. Disease development with oomycetes is generally enhanced in poorly drained soils, where orchards receive long durations of flood irrigation, or in trees in lower areas or along creeks and natural drainage creeks in the orchard [6]. When the soil remains saturated for a long time, these pathogens are able to infect susceptible roots.

Crespo et al. (2019) recently revealed species of Fusarium and Neocosmospora from declining pistachio rootstocks and stem cankers in the southern San Joaquin Valley of California that were pathogenic to this host [15]. Three Fusarium (Fusarium equiseti (Corda) Sacc., F. oxysporum Schltdl., and F. proliferatum (Matsush.) Nirenberg), and two Neocosmospora species (Neocosmospora falciformis (Carrión) L. Lombard and Crous (syn: Fusarium falciforme (Carrión) Summerb. and Schroers) and N. solani (Mart.) L. Lombard and Crous (syn: Fusarium solani (Mart.) Sacc.)) were found associated with crown rot symptoms and vascular discoloration in stems of clonal UCBI rootstocks in California [15]. Necrotic root lesions and black discoloration of the root cortex, epidermis, and vascular tissues associated with cylindrocarpon-like fungi included species in Dactylonectria, Neonectria, and Thelonectria, which were also detected in multiple counties in California [16].

Other disease symptoms observed in recent surveys of pistachio orchards have included young pistachio trees that were collapsing, showing crown rot with black discolorations in the rootstocks. Isolation from these young declining pistachio rootstocks revealed the occurrence of a single putative pathogen tentatively identified as a member of the Botryosphaeriaceae. The aims of this study were to (1) identify and characterize the putative pathogen associated with pistachio rootstock decline based on molecular and morphological methods; (2) test the pathogenicity of the putative pathogen on the commonly planted UCBI pistachio rootstock in California.

\section{Results}

\subsection{Field Surveys and Collection of Fungal Isolates}

Forty-two fungal isolates resembling a member of the Botryosphaeriaceae were isolated from the rootstock of young declining pistachio trees showing root crown and lower trunk rot symptoms (Figure 1). Affected rootstocks mainly included the clonal UCBI rootstocks. All pistachio isolates were obtained from orchards in Kern County, California. Orchards characteristics included heavy clay soils and history of vegetable crops or cotton. In addition to pistachio, 21 isolates with typical characteristics of the putative pathogen were also collected: 8 from sweet cherry in Fresno and San Joaquin Counties and 13 from grapevine in Fresno County. 

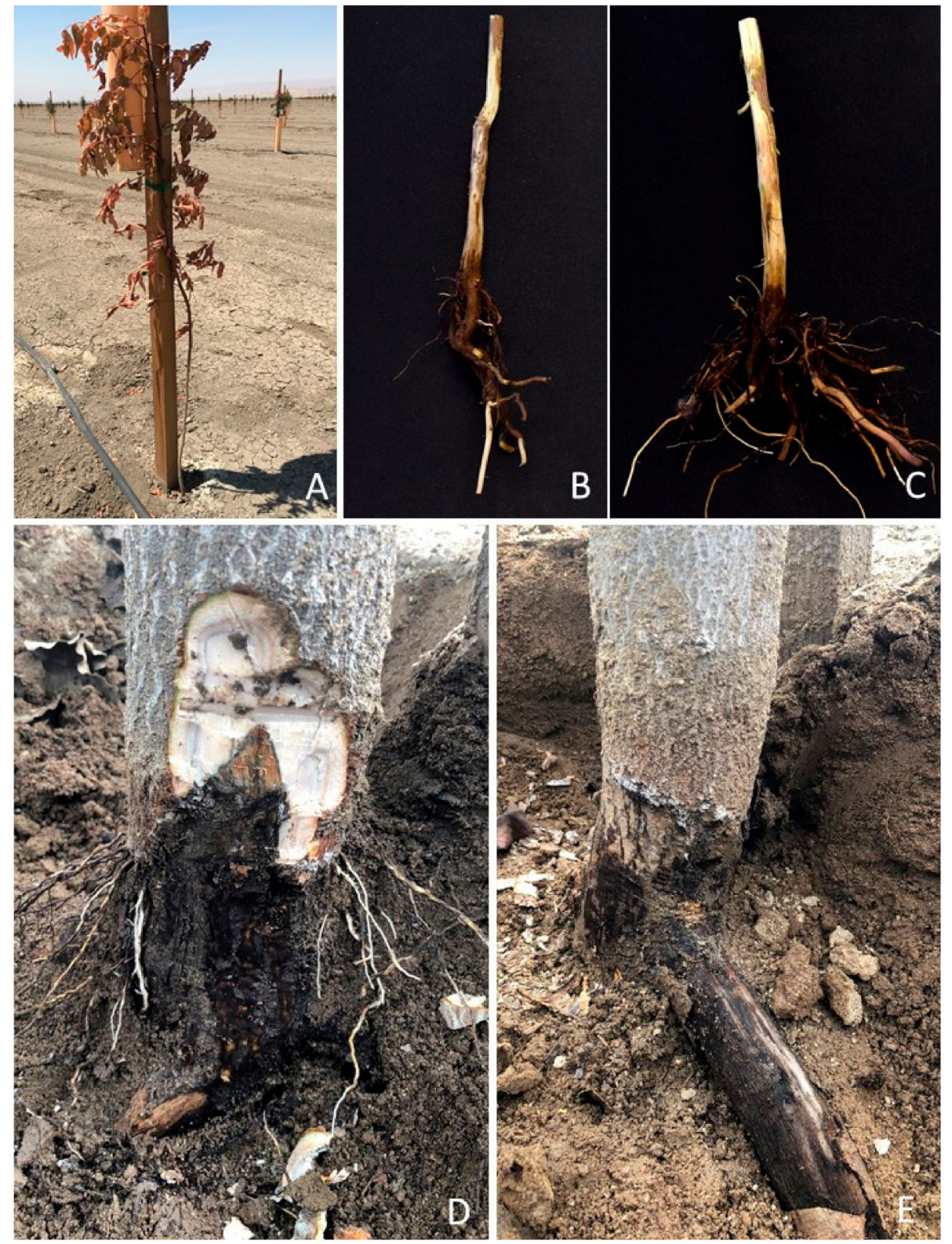

Figure 1. Symptoms in pistachio rootstocks associated with Macrophomina phaseolina; (A) wilting and death of unbudded University of California Berkeley I (UCBI) pistachio rootstocks; (B,C) associated crown rot symptom; $(\mathbf{D}, \mathbf{E})$ pistachio tree showing crown rot and black discoloration.

\subsection{Phylogenetic Analyses}

PCR amplification of the ITS region, TEF1, and TUB2 generated 452-498, 196-213, and 373-380 bp fragments, respectively. For ML analysis, the best-fit model of nucleotide evolution was $\mathrm{K} 2+\mathrm{G}$ for each dataset. The three-gene (ITS+TEF1+TUB2) 49 sequence dataset consisted of 1161 characters (643 characters were constant, 83 characters were parsimony-uninformative, and 435 characters were parsimony informative). MP analysis produced 30 equally most parsimonious trees of 996 steps and a consistency index (CI), retention index (RI), and rescaled consistency index (RC) of 0.776, 0.890, and 0.690, respectively. MP and ML analyses revealed that 30 Californian fungal isolates, isolated in this study, strongly clustered (100\%/100\% MP and ML bootstraps, respectively) with the type specimen of Macrophomina phaseolina (Tassi) Goid. isolate CBS 227.33 (Figure 2). 


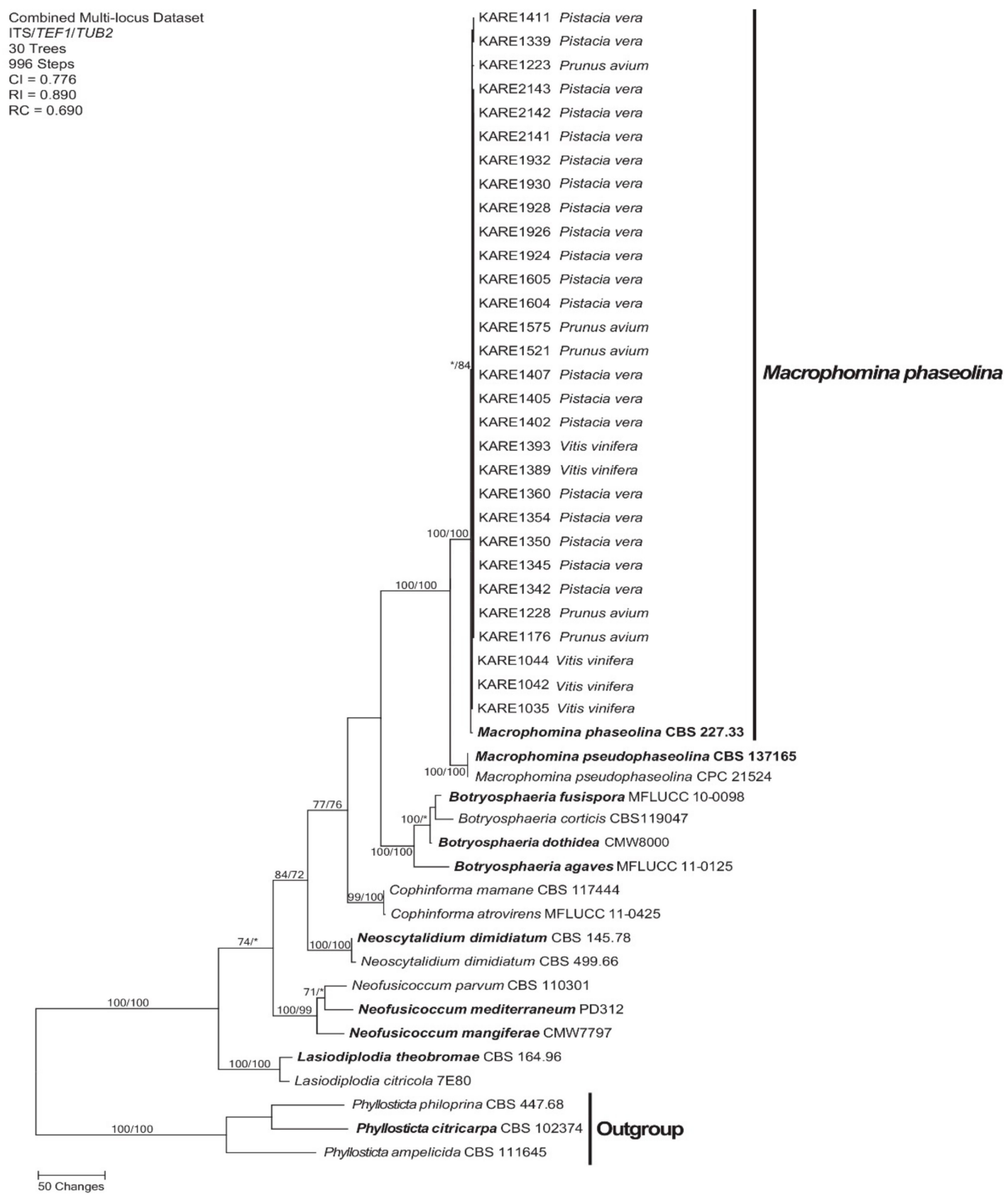

Figure 2. One of 30 equally most parsimonious trees resulting from the analysis of the three-gene combined dataset (ITS, TUB2, and TEF1). Numbers in front and after the slash represent maximum parsimony and maximum likelihood bootstrap values, respectively. Values represented by an asterisk were less than $70 \%$. Scale bar represents the number of nucleotide changes.

\subsection{Morphological Characterization}

Colonies in culture ranged in color from light to dark gray and became black with age (Figure 3A). The average growth rate was $4 \mathrm{~cm}$ per day, and most colonies reached the edge of an $85 \mathrm{~mm}$ potato dextrose agar (PDA) dish in $48 \mathrm{~h}$. Aerial mycelia generally did not develop on PDA. Hyphae were septate, initially subhyaline turning dark-brown with time. Abundant microsclerotia developed in water agar (WA) and PDA and were black, spherical to oblong, and averaged 84.5 (Length) $\times$ 53.5 (Width) $\mu \mathrm{m}(\mathrm{n}=40)$ with a length-width ratio of 1.57 at maturity (Figure 3B,C). Pycnidia, produced on pistachio leaf agar (PLA) medium after 2 weeks incubation, were black, subglobose to lageniform, solitary or gregarious, and ranged from 100 to $200 \mu \mathrm{m}$ in diameter. Conidia were ellipsoid to obovoid 
and averaged $24.5 \times 11.0 \mu \mathrm{m}$ with a length-width ratio of 2.28. Immature conidia possessed apical mucoid appendages (Figure 3D). Morphological features of the isolates were typical of those of $M$. phaseolina [17]. The optimal growth temperature was $30^{\circ} \mathrm{C}$ for all three isolates tested (Figure 4).
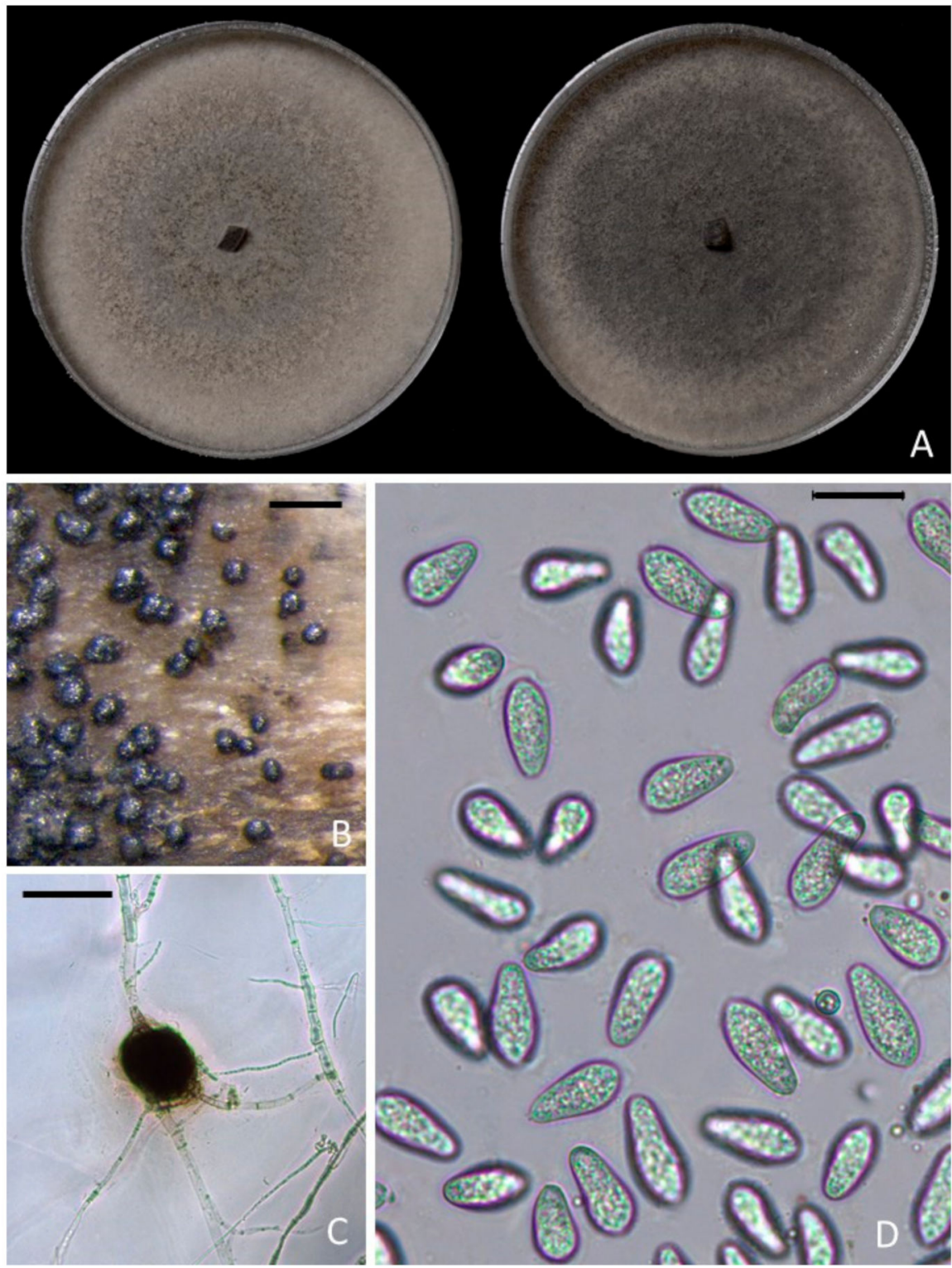

Figure 3. Morphological characteristics of Macrophomina phaseolina; (A) colonies on potato dextrose agar after 10 days of incubation at $25 \pm 1{ }^{\circ} \mathrm{C}$ in darkness; (B,C) microsclerotia on pistachio wood and close up on a microsclerotium produced on water agar; (D) conidia produced from mature pycnidia forming on pistachio leaf agar medium. Scale bar in $B=300 \mu \mathrm{m}$; in $C=60 \mu \mathrm{m}$; and in $\mathrm{D}=20 \mu \mathrm{m}$. 

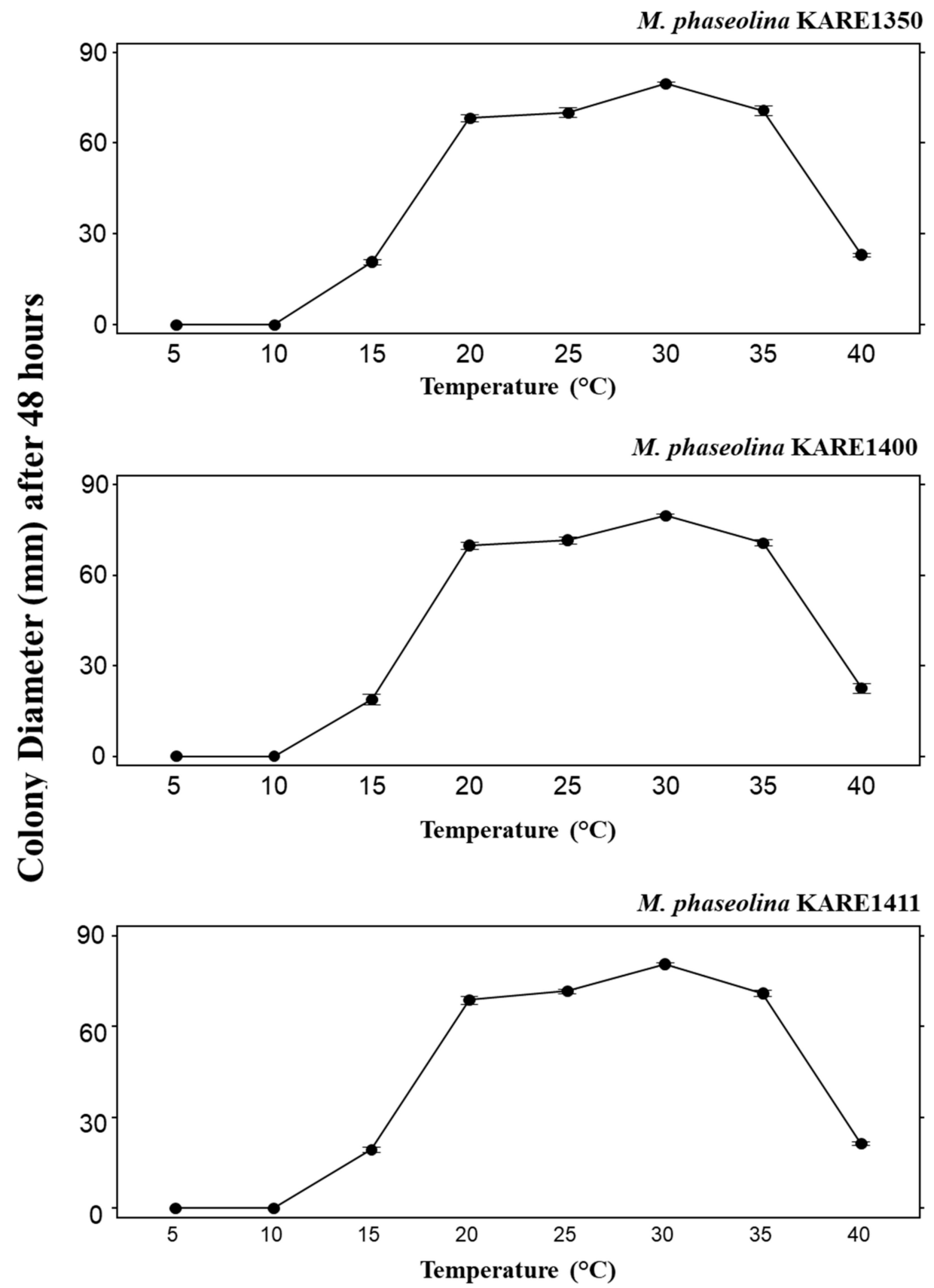

Figure 4. Effect of the temperature on the mycelial growth of three isolates of Macrophomina phaseolina: KARE1350, KARE1400 and KARE1411 on potato dextrose agar after $48 \mathrm{~h}$ of incubation. Error bars represent the standard error of the mean.

\subsection{Pathogenicity Tests}

\subsubsection{Stem Inoculation of Pistachio Rootstocks with Mycelium Plugs}

Ten months after inoculation, lesion and rot symptoms observed from the inoculated stems were similar to those observed in the field. For the first pathogenicity test conducted in September 2016, the two fungal isolates tested produced dark vascular discoloration in the wood that ranged from 4 to $4.76 \mathrm{~cm}$ in length (Figure 5). Both isolates tested produced significantly longer $(p=0.0005)$ lesion lengths on pistachio stems compared to the control treatment $(1.2 \mathrm{~cm})$. 


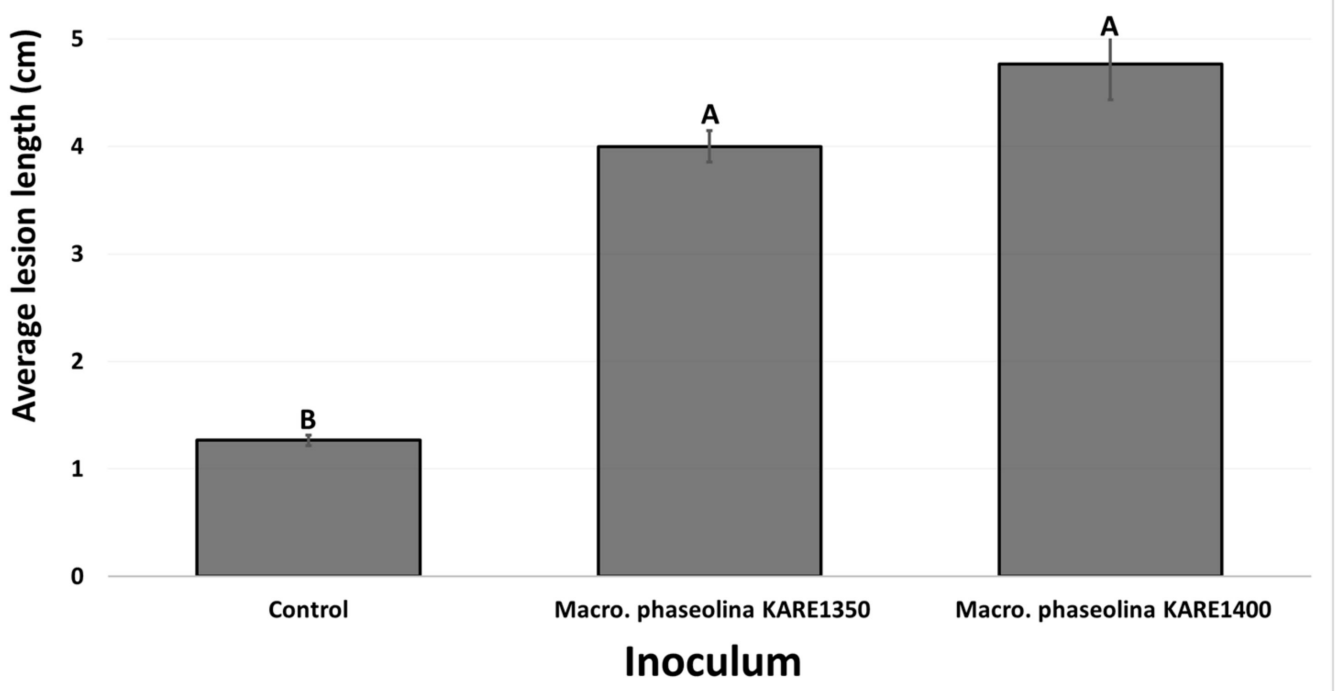

Figure 5. Average lesion lengths $(\mathrm{cm})$ on pistachio clonal UCBI rootstocks 10 months after inoculation with mycelial plugs of Macrophomina phaseolina isolates KARE1350 and KARE1400 (September 2016 inoculations). Columns with different letters indicate treatment means that are significantly different $(p=0.0005)$.

In the second experiment, conducted in July 2017, all three isolates tested produced substantial lesions to the stems of pistachio clonal UCB1 rootstocks (Figure 6). Mean lesion length varied between 16.15 and $16.83 \mathrm{~cm}$ and was significantly longer $(p<0.00001)$ as compared to the control plants $(2 \mathrm{~cm})$ (Figure 7). Each fungal isolate was successfully recovered from inoculated plants; pathogen recovery varied between $66.6 \%$ and $100 \%$ among the three isolates, and morphologically matched the inoculated fungus, thereby fulfilling Koch's postulates of pathogenic organisms. The controls showed no disease symptoms and no pathogen was isolated from them.

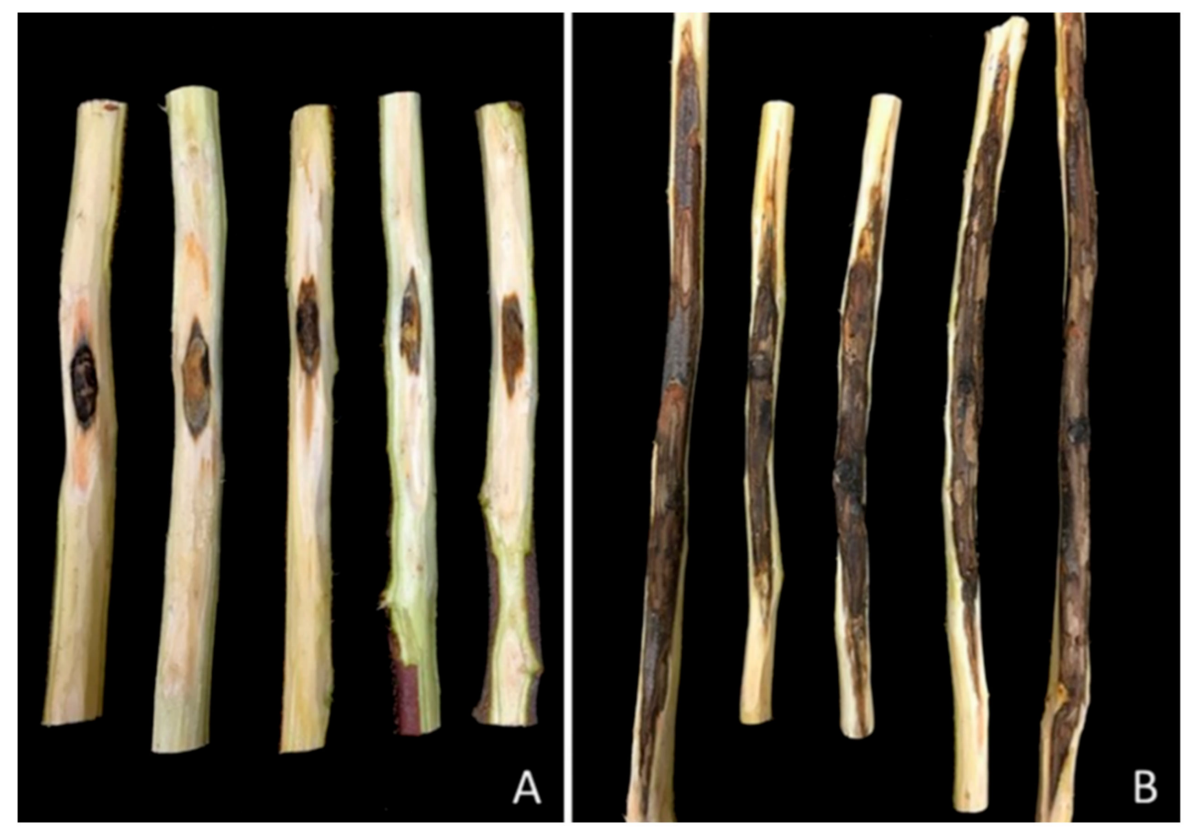

Figure 6. Lesions produced in 2-year-old potted clonal UCBI rootstocks, 10 months after inoculation: (A) Control; (B) Macrophomina phaseolina isolate KARE1400 (July 2017 inoculations). 


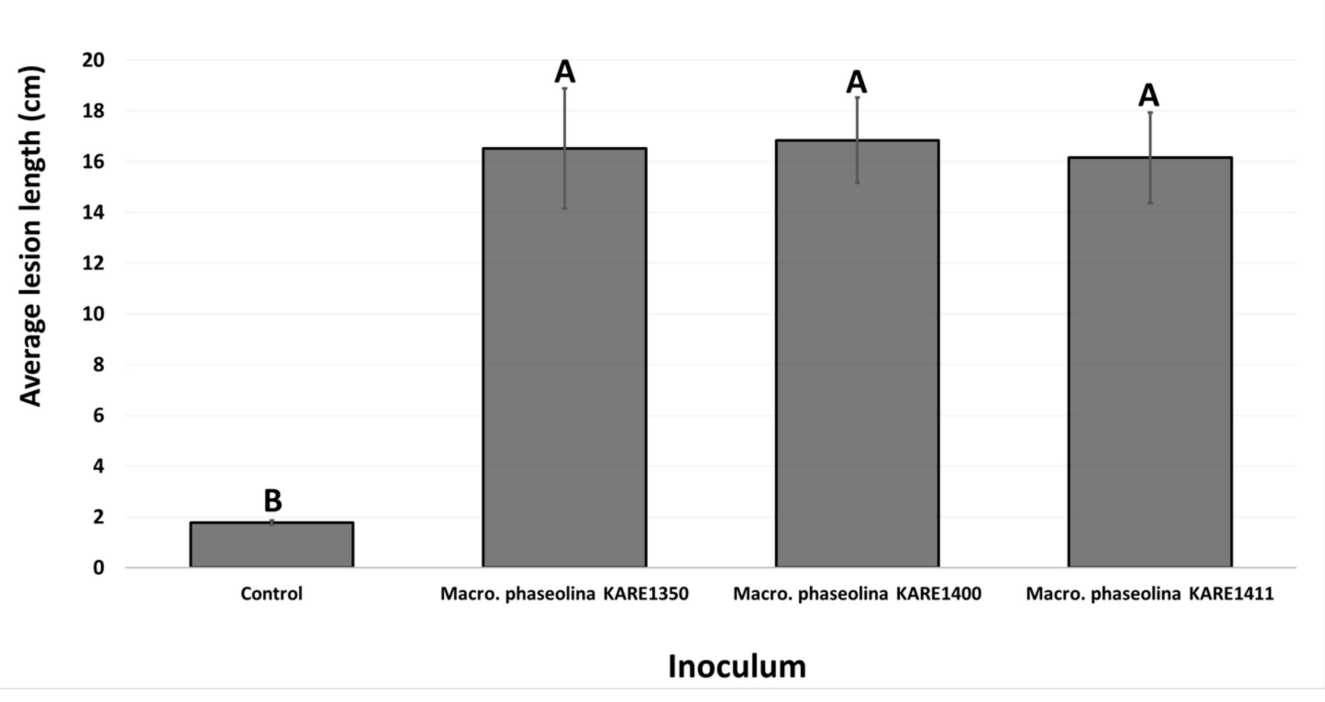

Figure 7. Average lesion lengths $(\mathrm{cm})$ on pistachio clonal UCBI rootstocks 10 months after inoculation with mycelial plugs of Macrophomina phaseolina isolates KARE1350, KARE1400, and KARE1411 (July 2017 inoculations). Columns with different letters indicate treatment means that are significantly different $(p<0.00001)$.

\subsubsection{Root Inoculation of Pistachio Rootstocks with Microsclerotial Suspension}

Three weeks after inoculation, all isolates tested had caused severe wilting or death of all the inoculated plantlets of clonal UCBI rootstocks (Figure 8). Isolates were recovered consistently from resulting root or crown lesions thus, fulfilling Koch's postulates. Macrophomina phaseolina was not isolated from control plants, which remained asymptomatic.

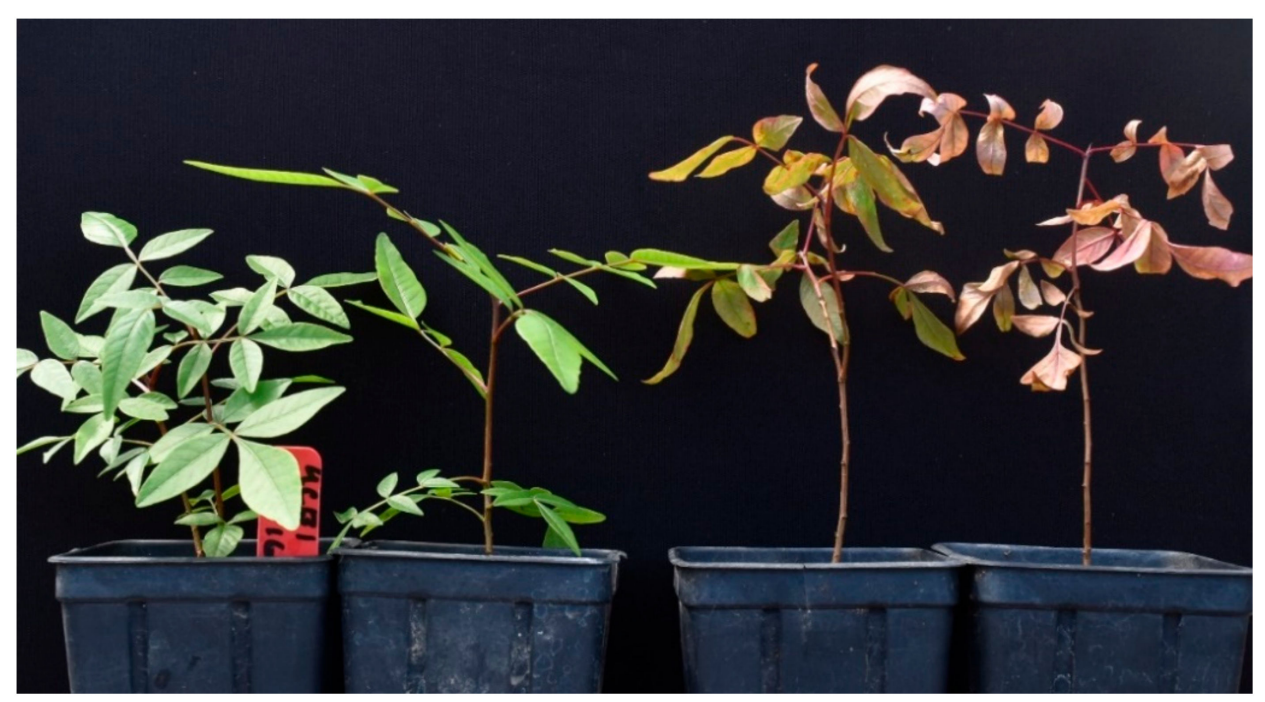

Figure 8. Symptoms produced on 4-month-old plantlets of clonal UCBI rootstocks after 22 days incubation and following root inoculation using a microsclerotia suspension with control plants (left) and inoculated plants (right).

\section{Discussion}

This is the first study to report M. phaseolina associated with pistachio rootstock decline in California. Macrophomina phaseolina was isolated from black lesions developing at the crown or basal stem of rapidly declining young pistachio trees in Kern County California. The identification of M. phaseolina was supported by morphological examinations of the unique colony characteristics, 
including fast growth and other anamorphic morphologies typical of the species including obtuse conidia with apical mucoid appendages and the production of microsclerotia in culture $[17,18]$.

Pathogen identification was confirmed by phylogenetic analyses of ITS, TEF1, and TUB2 DNA sequence data. These analyses revealed that isolates collected from different symptomatic parts in pistachio rootstocks (crown rot and root rot) represented a single species. Results of phylogenetic analyses also indicated that $M$. phaseolina isolates from pistachio were genetically similar to other isolates isolated from symptomatic grapevine and sweet cherry in Fresno and San Joaquin Counties, respectively.

Macrophomina phaseolina is an important phytopathogenic fungus, infecting more than 750 plant species $[17,19]$. The pathogen incites a stem canker disease in many crops that is often referred to as charcoal rot disease, due to the charcoal type coloration imparted to the symptomatic plant tissues. Charcoal rot disease affects many field crops including soybean (Glycine max (L.) Merr.) [20], chickpea (Cicer arietinum L.) [21], common bean (Phaseolus vulgaris L.) [22], sunflower (Helianthus annuus L.) [23], and sorghum (Sorghum bicolor (L.) Moench.) [24]. In California, charcoal rot has emerged as a serious concern for strawberry cultivation [25]. By 2014, the pathogen was confirmed in all major coastal strawberry counties in California [26]. Macrophomina phaseolina has been reported only sporadically as a pathogen of perennial woody crops. It is known to affect grapevine in Australia, Iran, South Africa, Spain, and California [27-29] and olive in Australia [30]. In California, M. phaseolina has also been reported from almond cankers [31].

Pathogenicity tests in potted 2-year-old clonal UCBI pistachio rootstocks using mycelium plugs showed that M. phaseolina was highly aggressive following July infections, causing dark and elongated lesions in the stems of the pistachio trees. In the microsclerotial inoculum assay, M. phaseolina caused the death of clonal UCBI pistachio plantlets, inducing both root and crown rots. These results indicate that clonal UCBI pistachio rootstock most likely do not possess genetic resistance against this aggressive plant pathogen. To our knowledge, this work is the first to report M. phaseolina associated with the decline of pistachio trees worldwide.

Macrophomina phaseolina causes important annual losses to its host crop and can survive in the soil for many years, mainly as microsclerotia that germinate repeatedly during the growing season. The pathogen generally attacks young plants when their growth is retarded due to unfavorable conditions including low-water potentials that occur during periods of severe drought [32]. In the present study, M. phaseolina was mostly isolated from young rootstocks that were newly planted in the field and were subjected to stressful environmental conditions such as high temperature, poor soil fertility, or trees that had suffered bark damage due to gophers.

In recent years, California has been severely affected by drought and increased mean annual temperatures, which may contribute to fluxes in the plant environment and increase plant stress. Water shortage combined with high temperatures, the intensification and expansion of pistachio cultivation, the aging of orchards, and the planting of new varieties are also factors that could contribute to disease emergence and spread. Recently, multiple Cytospora spp., Neofusicoccum mediterraneum, Colletotrichum karsti You L. Yang, Zuo Y. Liu, K.D. Hyde and L. Cai, Diaporthe ambigua Nitschke, and Didymella glomerata (Corda) Qian Chen and L. Cai, were reported as new pathogens of pistachio in California, causing cankers in the trunks and branches of mature trees [4,5].

In conclusion, this study has provided new information regarding the identity and pathogenicity of M. phaseolina associated with pistachio rootstock decline in California, and this pathogen represents a new and emerging threat to the industry. The occurrence of this fungal pathogen, in pistachio but also sweet cherry and grapevine in California, has become of increasing concern in recent years. Research needs to be continued to investigate the disease epidemiology as well as develop efficient control strategies to mitigate the impact of Macrophomina crown and root rot disease of pistachio in California. 


\section{Materials and Methods}

\subsection{Field Surveys and Collection of Fungal Isolates}

Isolates used in this study were isolated from declining pistachio trees and rootstocks expressing crown and root rot symptoms in Kern County California from 2016 to 2018. In total, 22 symptomatic samples were collected from 8 orchards ranging from 1- to 5-years-old. Samples of phloem (live bark) and vascular-cambium tissue from the lower trunk/crown of young trees showing crown rot and associated decline symptoms were collected and taken to the laboratory for detailed examination and isolation of putative pathogens. Symptomatic bark and root tissues were surface disinfested by submerging them in a $0.5 \%$ sodium hypochlorite for $2 \mathrm{~min}$ and rinsed twice with sterile water. Subsequently, the bark and root tissues were placed in Petri dishes containing potato dextrose agar (PDA) acidified with lactic acid $(2.5 \mathrm{~mL}$ of $25 \%$ [vol/vol] per liter of medium) (APDA). Cultures were incubated at ambient laboratory light and temperature conditions $\left(24 \pm 2{ }^{\circ} \mathrm{C}\right)$ with approximately $12 \mathrm{~h}$ of daylight and $12 \mathrm{~h}$ of darkness until fungal colonies were observed. The most prevalent fungal taxa growing from the symptomatic tissues were then individually transferred to fresh APDA Petri dishes. To obtain pure cultures, single hyphal tips from colonies with typical growth characteristics of the Botryosphaeriaceae (initially white, fast-growing, and darkening with age) were transferred to fresh PDA and incubated as described above for 5 to 7 days. Similar isolates were also isolated from symptomatic grapevine and sweet cherry wood tissues and were included in the phylogenetic analyses. Isolates collected in the present study are summarized in Table 1 and maintained in the culture collection of the Department of Plant Pathology of the University of California, Davis at the Kearney Agricultural Research and Extension (KARE) Center, Parlier, CA, USA. 
Table 1. Fungal isolates recovered in this study.

\begin{tabular}{|c|c|c|c|c|c|c|c|}
\hline \multirow{2}{*}{ Species } & \multirow{2}{*}{ Isolate $^{a}$} & \multirow{2}{*}{ Host } & \multirow{2}{*}{ Substrate } & \multirow{2}{*}{ Location } & \multicolumn{3}{|c|}{ GenBank Accession Number ${ }^{b}$} \\
\hline & & & & & ITS & TEF1 & TUB2 \\
\hline Macrophomina phaseolina & KARE1339 & Pistacia vera & Crown & Kern Co., CA & MN097202 & MN106057 & MN106087 \\
\hline Macrophomina phaseolina & KARE1342 & Pistacia vera & Crown & Kern Co., CA & MN097203 & MN106058 & MN106088 \\
\hline Macrophomina phaseolina & KARE1345 & Pistacia vera & Root & Kern Co., CA & MN097204 & MN106059 & MN106089 \\
\hline Macrophomina phaseolina & KARE1350 & Pistacia vera & Crown & Kern Co., CA & MN097205 & MN106060 & MN106090 \\
\hline Macrophomina phaseolina & KARE1354 & Pistacia vera & Crown & Kern Co., CA & MN097206 & MN106061 & MN106091 \\
\hline Macrophomina phaseolina & KARE1360 & Pistacia vera & Root & Kern Co., CA & MN097207 & MN106062 & MN106092 \\
\hline Macrophomina phaseolina & KARE1402 & Pistacia vera & Crown & Kern Co., CA & MN097210 & MN106065 & MN106095 \\
\hline Macrophomina phaseolina & KARE1405 & Pistacia vera & Crown & Kern Co., CA & MN097211 & MN106066 & MN106096 \\
\hline Macrophomina phaseolina & KARE1407 & Pistacia vera & Crown & Kern Co., CA & MN097212 & MN106067 & MN106097 \\
\hline Macrophomina phaseolina & KARE1411 & Pistacia vera & Root & Kern Co., CA & MN097213 & MN106068 & MN106098 \\
\hline Macrophomina phaseolina & KARE1604 & Pistacia vera & Crown & Kern Co., CA & MN097216 & MN106069 & MN106101 \\
\hline Macrophomina phaseolina & KARE1605 & Pistacia vera & Crown & Kern Co., CA & MN097217 & MN106070 & MN106102 \\
\hline Macrophomina phaseolina & KARE1924 & Pistacia vera & Crown & Kern Co., CA & MN097218 & MN106073 & MN106103 \\
\hline Macrophomina phaseolina & KARE1926 & Pistacia vera & Crown & Kern Co., CA & >MN097219 & MN106074 & MN106104 \\
\hline Macrophomina phaseolina & KARE1928 & Pistacia vera & Crown & Kern Co., CA & MN097220 & MN106075 & MN106105 \\
\hline Macrophomina phaseolina & KARE1930 & Pistacia vera & Crown & Kern Co., CA & MN097221 & MN106076 & MN106106 \\
\hline Macrophomina phaseolina & KARE1932 & Pistacia vera & Crown & Kern Co., CA & MN097222 & MN106077 & MN106107 \\
\hline Macrophomina phaseolina & KARE2141 & Pistacia vera & Crown & Kern Co., CA & MN097223 & MN106078 & MN106108 \\
\hline Macrophomina phaseolina & KARE2142 & Pistacia vera & Crown & Kern Co., CA & MN097224 & MN106079 & MN106109 \\
\hline Macrophomina phaseolina & KARE2143 & Pistacia vera & Crown & Kern Co., CA & MN097225 & MN106080 & MN106110 \\
\hline Macrophomina phaseolina & KARE1176 & Prunus avium & Root & San Joaquin Co., CA & MN097199 & MN106054 & MN106084 \\
\hline Macrophomina phaseolina & KARE1223 & Prunus avium & Root & San Joaquin Co., CA & MN097200 & MN106055 & MN106085 \\
\hline Macrophomina phaseolina & KARE1228 & Prunus avium & Root & San Joaquin Co., CA & MN097201 & MN106056 & MN106086 \\
\hline Macrophomina phaseolina & KARE1521 & Prunus avium & Root & Fresno Co., CA & MN097214 & MN106071 & MN106099 \\
\hline Macrophomina phaseolina & KARE1575 & Prunus avium & Root & Fresno Co., CA & MN097215 & MN106072 & MN106100 \\
\hline Macrophomina phaseolina & KARE1035 & Vitis vinifera & Trunk & Fresno Co., CA & MN097196 & MN106051 & MN106081 \\
\hline Macrophomina phaseolina & KARE1042 & Vitis vinifera & Cordon & Fresno Co., CA & MN097197 & MN106052 & MN106082 \\
\hline Macrophomina phaseolina & KARE1044 & Vitis vinifera & Cordon & Fresno Co., CA & MN097198 & MN106053 & MN106083 \\
\hline Macrophomina phaseolina & KARE1389 & Vitis vinifera & Trunk & Fresno Co., CA & MN097208 & MN106063 & MN106093 \\
\hline Macrophomina phaseolina & KARE1393 & Vitis vinifera & Trunk & Fresno Co., CA & MN097209 & MN106064 & MN106094 \\
\hline
\end{tabular}

${ }^{\mathrm{a}} \mathrm{KARE}=$ Kearney Agricultural Research and Extension. ${ }^{\mathrm{b}}$ ITS $=$ internal transcribed spacer, TEF1 $=$ translation elongation factor $1 \alpha$, and TUB2 $=$ beta-tubulin 


\subsection{DNA Extraction, Sequencing, and Phylogenetic Analyses}

Total genomic DNA was isolated from fungal mycelium scraped with a sterile scalpel from the surface of 7-day-old PDA cultures using the DNeasy Plant Kit (Qiagen, Valencia, CA, USA), following the manufacturer's instructions. All PCR reactions utilized AccuPower ${ }^{\mathrm{TM}}$ PCR Premix (Bioneer, Alameda, CA, USA), following the manufacturer's instructions. Amplification of rDNA, including the intervening ITS regions and 5.8S rDNA (ITS1-5.8S-ITS2), using the primer set ITS1 and ITS4 followed the protocol of White et al. (1990) [33]. Amplification of translation elongation factor 1- $\alpha$ (TEF1) fragments utilized the primer set EF1-728F and EF1-986R [34], and beta-tubulin (TUB2) utilized primers Bt2a and Bt2b [35]. PCR products were visualized on 1.5\% agarose gels (120 V for $25 \mathrm{~min}$ ) stained with GelRed ${ }^{\circledR}$ (Biotium, Fremont, CA, USA), following the manufacturer's instructions, to confirm presence and size of PCR amplicons, purified via Exonuclease I and recombinant Shrimp Alkaline Phosphatase (Affymetrix, Santa Clara, CA, USA), and sequenced in both directions utilizing the primers above on an ABI 3730 Capillary Electrophoresis Genetic Analyzer (College of Biological Sciences Sequencing Facility, University of California, Davis, CA, USA).

Forward and reverse DNA sequences were assembled, edited, and proofread in Sequencher v. 5 (Gene Codes Corporation, Ann Arbor, MI, USA) and deposited in GenBank (Table 1). Homologous sequences with high similarity from ex-type and non-type Botryosphaeriaceae species were included for phylogenetic reference utilizing the BLASTn function in NCBI and literature review (Table 2). Multiple sequence alignments were conducted in MEGA v. 6 [36] and manually adjusted where necessary in Mesquite v. 3.10 [37]. Alignments were submitted to TreeBASE under accession number S24559. The three-gene dataset was analyzed using two different optimality search criteria, maximum parsimony (MP) and maximum likelihood (ML), in PAUP * v. 4.0a164 and GARLI v. 0.951 [38,39], respectively. For the MP analysis, a heuristic search with 1000 random sequence additions was implemented with the Tree-Bisection-Reconnection algorithm and gaps were treated as missing data. Bootstrap analysis with 1000 replicates was used to estimate branch support. For the ML analysis, MEGA was used to infer a model of nucleotide substitution for each dataset, using the Akaike Information Criterion (AIC). ML analyses were conducted according to the best fit model of nucleotide substitution for each dataset using default parameters in GARLI, and branch support was determined by 1000 bootstrap replicates. Sequences of Phyllosticta Pers. (Botryosphaeriales, Phyllostictaceae) served as the outgroup taxon in the phylogenetic analyses. 
Table 2. Fungal isolates retrieved from Genbank for phylogenetic reference.

\begin{tabular}{|c|c|c|c|c|c|c|}
\hline \multirow{2}{*}{ Species } & \multirow{2}{*}{ Isolate $^{a}$} & \multirow{2}{*}{ Host/Substrate } & \multirow{2}{*}{ Location } & \multicolumn{3}{|c|}{ GenBank Accession Number ${ }^{b}$} \\
\hline & & & & ITS & TEF1 & TUB2 \\
\hline Botryospheria agaves & MFLUCC 11-0125 & Agaves sp. & Thailand & JX646791 & JX646856 & JX646841 \\
\hline Botryospheria corticis & CBS 119047 & Vaccinium corymbosum & NJ, USA & DQ299245 & EU017539 & EU673107 \\
\hline Botryospheria dothidea & CMW8000 & Prunus sp. & Switzerland & AY236949 & AY236898 & AY236927 \\
\hline Botryospheria fusispora & MFLUCC 10-0098 & Caryota sp. & Thailand & JX646789 & JX646854 & JX646839 \\
\hline Cophinforma eucalypti & MFLUCC 11-0425 & Eucalyptus sp. & Thailand & JX646800 & JX646865 & JX646848 \\
\hline Cophinforma mamane & CBS 117444 & Eucalyptus sp. & Venezuela & KF531822 & KF531801 & KF531802 \\
\hline Lasiodiplodia theobromae & CBS 164.96 & Fruit on coral reef coast & New Guinea & AY640255 & AY640258 & EU673110 \\
\hline Lasiodiplodia citricola & 7-E80 & Juglans regia & CA, USA & КС357300 & KC357312 & KC357306 \\
\hline Macrophomina phaseolina & CBS 227.33 & Zea mays & Palestine & KF531825 & KF531804 & KF531806 \\
\hline Macrophomina pseudophaseolina & CBS 137165 & Arachis hypogaea & Senegal & KF951791 & KF952153 & KF952233 \\
\hline Macrophomina pseudophaseolina & СРC 21524 & Hibiscus sabdarifa & Senegal & KF951799 & KF952161 & KF952240 \\
\hline Neofusicoccum mangiferae & CBS 118532 & Mangifera indica & Australia & AY615186 & DQ093220 & AY615173 \\
\hline Neofusicoccum mediterraneum & PD312 & Eucalyptus sp. & Greece & GU251176 & GU251308 & GU251836 \\
\hline Neofusicoccum parvum & CBS 110301 & Vitis vinifera & Portugal & AY259098 & AY573221 & EU673095 \\
\hline Neoscytalidium dimidiatum & CBS 145.78 & Homo sapiens & United Kingdom & KF531816 & KF531795 & KF531796 \\
\hline Neoscytalidium dimidiatum & CBS 499.66 & Mangifera indica & Mali & KF531820 & KF531798 & KF531800 \\
\hline Phyllosticta ampelicida & CBS 111645 & Parthenocissus quinquefolia & MO, USA & FJ824766 & FJ824772 & FJ824777 \\
\hline Phyllosticta citricarpa & CBS 102374 & Citrus aurantium & Brazil & FJ824767 & FJ538371 & FJ824778 \\
\hline Phyllosticta philoprina & CBS 447.68 & Taxus baccata & United States & FJ824768 & FJ824773 & FJ824779 \\
\hline
\end{tabular}

${ }^{\mathrm{a}}$ Isolates in bold represent type specimens. ${ }^{\mathrm{b}}$ ITS $=$ internal transcribed spacer, TEF1 = translation elongation factor $1 \alpha$, and TUB2 = beta-tubulin. 


\subsection{Morphological Characterization}

Three representative isolates (KARE1045, KARE1350, and KARE1400) were selected to study their cultural and conidial features. For each selected isolate, $5 \mathrm{~mm}$ mycelial plugs from developing colonies were removed and transferred to the center of new $85 \mathrm{~mm}$ diameter PDA Petri dishes. Cultures were incubated in the dark at temperatures ranging from 5 to $40{ }^{\circ} \mathrm{C}$ at 5 -degree intervals. At each temperature $\left(5^{\circ}, 10^{\circ}, 15^{\circ}, 20^{\circ}, 25^{\circ}, 30^{\circ}, 35^{\circ}\right.$, and $\left.40^{\circ} \mathrm{C}\right), 3$ replicate dishes of each isolate were used. Measurements of colony diameter were taken each $24 \mathrm{~h}$ until the fastest-growing colony had reached the edge of the dish. For each of the 8 temperatures, the average colony diameter per $48 \mathrm{~h}$ of growth was calculated. Colony characters and pigment production were noted after $48 \mathrm{~h}$ of incubation on PDA at $30^{\circ} \mathrm{C}$ in darkness. The experiment was repeated once.

The representative isolates, as mentioned above, were further used to study conidial morphology. Pycnidia were induced to form by incubating colonies on pistachio leaf agar (PLA) medium [40]. Pistachio leaves were autoclaved twice at $120^{\circ} \mathrm{C}$ for $20 \mathrm{~min}$ and then placed into Petri dishes containing PDA ( $5 \mathrm{~g}$ agar, $5 \mathrm{~g}$ potato dextrose broth and $500 \mathrm{~mL}$ water). Cultures were then incubated under near UV irradiation ( $12 \mathrm{~h}$ light/12 h dark) at $25 \pm 1{ }^{\circ} \mathrm{C}$ for 2 weeks. Pycnidia containing conidia were mounted in sterile water on glass slides, and conidial dimensions included length and width of 40 conidia for each isolate were measured at $\times 400$ magnification using a Leica compound microscope (Leica DM2000 LED Microscope, Wetzlar, Germany). Microsclerotia were also induced to form by incubating isolates on WA and characterized as described above.

\subsection{Pathogenicity Tests}

\subsubsection{Stem Inoculation of Clonal UCBI Pistachio Rootstocks with Mycelium Plugs}

Potted 2-year-old clonal UCBI pistachio rootstocks showing no apparent decline symptoms, or weak growth, were used for the pathogenicity tests. Two experiments were conducted using the same methodology. The first pathogenicity test was conducted in September 2016. Four tree replicates were inoculated per combination of 3 inoculation treatments (isolates KARE1350, KARE1400, and the control). Plants were arranged in a completely randomized design and maintained in a greenhouse with a natural photoperiod and temperatures ranging from 22 to $30{ }^{\circ} \mathrm{C}$ for 10 months. Plants were watered once weekly during the course of the experiment. The second pathogenicity test was conducted in July 2017. Eight replicate trees were inoculated per combination of 4 inoculation treatments (isolates KARE1350, KARE1400, KARE1411, and the control) and arranged in a completely randomized design in an outdoor gravel bed for 10 months. Inoculations were conducted by using a $5 \mathrm{~mm}$-diameter mycelium plug from a 7-day-old culture. The bark surface was disinfected at the point of inoculation with $70 \%$ ethanol. Stems of the potted clonal UCBI rootstocks were inoculated $4 \mathrm{~cm}$ above the soil line, wounds to the stem/crown were produced with a flame-sterilized $5 \mathrm{~mm}$ cork borer followed by placing a $5 \mathrm{~mm}$ agar plug bearing aerial mycelia, upper surface facing inward, into the fresh wound, which was then sealed with petroleum jelly, and wrapped with Parafilm. Control plants were treated with sterile PDA agar plugs followed by sealing and wrapping as above. Plants were watered twice weekly.

Infection data were recorded 10 months after inoculation. The bark was removed, and the length of wood discoloration (LWD) upwards and downwards from the point of inoculation was measured using a digital caliper. In an attempt to fulfill Koch's postulates, small pieces of necrotic tissue from the edge of each lesion were surface disinfested as described above and plated on APDA filled Petri dishes to recover the inoculated fungus. Emerging fungal colonies were recorded and identified based on morphology as described above. Data for lesion length were tested for normality and homogeneity of variance using Shapiro-Wilk's and Bartlett's tests, respectively. ANOVAs were done in Statistix 10 (Analytical Software, Tallahassee, FL, USA) to evaluate differences in the LWD between the control and fungal treatments. Differences in the means between fungal treatments and the mock-inoculated controls were assessed using Tukey's honestly significant difference (HSD) test at $p=0.05$. 


\subsubsection{Root Inoculation of UCBI Pistachio Rootstocks with Microsclerotial Suspensions}

Clonal UCBI pistachio saplings were root-inoculated using a microsclerotial suspension. The experiment was conducted using 3 isolates (KARE1350, KARE1400, and KARE1411) of M. phaseolina inoculated to 4-month-old plantlets of clonal UCBI rootstocks. The inoculum, consisting of mycelium and microsclerotia $\left(1 \times 10^{5}\right.$ propagules per $\left.\mathrm{mL}\right)$, was prepared by scraping the surface of 12 -day-old PDA cultures containing microsclerotia of the pathogen with a sterile scalpel blade and homogenizing in sterile water using a kitchen blender on high speed for $30 \mathrm{~s}$. Inoculations were performed by dipping the bare root system of each rootstock into the inoculum slurry for $5 \mathrm{~min}$, and subsequently mixing the microsclerotia suspension homogeneously with potting soil in $10 \times 24 \mathrm{~cm}$ tree pots. In total, 20 clonal UCBI plantlet rootstocks were used. These included 5 replicates for each fungal isolate and the control. The 5 mock-inoculated controls were subjected to the same process as described above but were treated with a mixture of distilled sterile water and potted and incubated as above. Disease development and symptoms were assessed every 4 days for 1 month.

Author Contributions: Conceptualization, F.P.T. and M.T.N.; methodology, M.T.N., D.P.L., and F.P.T.; software, D.P.L. and M.T.N.; formal analysis, D.P.L. and M.T.N.; surveys, F.P.T., C.E.K. and M.T.N.; writing-original draft preparation, M.T.N.; writing-review and editing, F.P.T. and D.P.L.; supervision, F.P.T.; funding acquisition, F.P.T. All authors have read and agreed to the published version of the manuscript.

Funding: This research was funded by the California Pistachio Research Board (CPRB).

Conflicts of Interest: The authors declare no conflict of interest.

\section{References}

1. Michailides, T.J. Pathogenicity, distribution, sources of inoculum, and infection courts of Botryosphaeria dothidea on pistachio. Phytopathology 1991, 81, 566-573. [CrossRef]

2. Michailides, T.J. Pest, Disease, and Physiological Disorders Management: Above Ground Fungal Diseases. 2005. Available online: http://fruitsandnuts.ucdavis.edu/files/73707.pdf (accessed on 14 August 2019).

3. Pryor, B.M.; Michailides, T.J. Morphological, Pathogenic, and Molecular Characterization of Alternaria isolates associated with Alternaria late blight of pistachio. Phytopathology 2002, 92, 406-416. [CrossRef]

4. Lawrence, D.P.; Holland, L.A.; Nouri, M.T.; Travadon, R.; Abramians, A.; Michailides, T.J.; Trouillas, F.P. Molecular phylogeny of Cytospora species associated with canker diseases of fruit and nut crops in California, with the descriptions of ten new species and one new combination. IMA Fungus 2018, 9, 333-370. [CrossRef] [PubMed]

5. Nouri, M.T.; Lawrence, D.P.; Holland, L.A.; Doll, D.A.; Kallsen, C.E.; Culumber, C.M.; Trouillas, F.P. Identification and pathogenicity of fungal species associated with canker diseases of pistachio in California. Plant Dis. 2019, 103, 2397-2411. [CrossRef] [PubMed]

6. Holtz, B.A.; Teviotdale, B.L. Soil-borne diseases. In Pistachio Production Manual; Ferguson, L., Haviland, D., Eds.; University of California Agriculture and Natural Resources: Oakland, CA, USA, 2016; pp. 257-264.

7. Fradin, E.F.; Thomma, B.P.H.J. Physiology and molecular aspects of Verticillium wilt diseases caused by $V$. dahliae and V. albo-atrum. Mol. Plant Pathol. 2006, 7, 71-86. [CrossRef] [PubMed]

8. Pegg, G.F.; Brady, B.L. Verticillium Wilts; CAB International: Oxon, UK, 2002.

9. Klosterman, S.J.; Atallah, Z.K.; Vallad, G.E.; Subbarao, K.V. Diversity, pathogenicity and management of Verticillium species. Annu. Rev. Phytopathol. 2009, 47, 39-62. [CrossRef]

10. Epstein, L.; Beede, R.; Kaur, S.; Ferguson, L. Rootstock effects on pistachio trees grown in Verticillium dahliae-infested soil. Phytopathology 2004, 94, 388-395. [CrossRef]

11. Ogawa, J.M.; English, H. Diseases of Temperate Zone Tree Fruit and Nut Crops; UC ANR Publications: Oakland, CA, USA, 1991.

12. Fichtner, E.J.; Kallsen, C.E.; Blomquist, C.L. First report of crown rot caused by Phytophthora parsiana on pistachio in the Southern San Joaquin Valley, California. Plant Dis. 2016, 100, 1795. [CrossRef]

13. Fichtner, E.J.; Browne, G.T.; Mortaz, M.; Ferguson, L.; Blomquist, C.L. First report of root rot caused by Phytopythium helicoides on pistachio rootstock in California. Plant Dis. 2016, 100, 2337. [CrossRef] 
14. MacDonald, J.D.; Banihashemi, Z.; Mircetich, S.M.; Browne, G.; Bolkan, L. Trunk and branch canker of pistachio caused by Phytophthora spp. Phytopathology 1992, 82, 1089.

15. Crespo, M.; Lawrence, D.P.; Nouri, M.T.; Doll, D.A.; Trouillas, F.P. Characterization of Fusarium and Neocosmospora species associated with crown rot and stem canker of pistachio rootstocks in California. Plant Dis. 2019, 103, 1931-1939. [CrossRef] [PubMed]

16. Lawrence, D.P.; Nouri, M.T.; Trouillas, F.P. Taxonomy and multi-locus phylogeny of cylindrocarpon-like species associated with diseased roots of grapevine and other fruit and nut crops in California. FUSE 2019, 4, 59-75. [CrossRef]

17. Sarr, M.P.; Ndiaye, M.B.; Groenewald, J.Z.; Crous, P.W. Genetic diversity in Macrophomina phaseolina, the causal agent of charcoal rot. Phytopathol. Mediterr. 2014, 53, 250-268.

18. Crous, P.W.; Slippers, B.; Wingfield, M.J.; Rheeder, J.; Marasas, W.F.O.; Philips, A.J.L.; Alves, A.; Burgess, T.; Barber, P.; Groenewald, J.Z. Phylogenetic lineages in the Botryosphaeriaceae. Stud. Mycol. 2006, 55, 235-253. [CrossRef]

19. Baird, R.E.; Watson, C.E.; Scruggs, M. Relative longevity of Macrophomina phaseolina and associated mycobiota on residual soybean roots in soil. Plant Dis. 2003, 87, 563-566. [CrossRef]

20. Mengistu, A.; Wrather, A.; Rupe, J.C. Charcoal rot. In Compendium of Soybean Diseases and Pests, 5th ed.; Hartman, G.L., Rupe, J.C., Sikora, E.J., Domier, L.L., Davies, J.A., Steffey, L.K., Eds.; APS Press: Saint Paul, MN, USA, 2015; pp. 67-69.

21. Srivastava, A.K.; Singh, T.; Jana, T.K.; Arora, D.K. Microbial colonization of Macrophomina phaseolina and suppression of charcoal rot of chickpea. In Microbes and Plants; Sinha, A., Ed.; Vedamse Books (P) Ltd.: New Delhi, India, 2001; pp. 269-319.

22. Mayék-Pérez, N.; Garcia-Espinosa, R.; López-Castañeda, C.; Acosta-Gallegos, J.A.; Simpson, J. Water relations, histopathology and growth of common bean (Phaseolus vulgaris L.) during pathogenesis of Macrophomina phaseolina under drought stress. Physiol. Mol. Plant Pathol. 2002, 60, 185-195. [CrossRef]

23. Bokor, P. Macrophomina phaseolina causing a charcoal rot of sunflower through Slovakia. Biologia 2007, 62, 136-138. [CrossRef]

24. Sharma, I.; Kumari, N.; Sharma, V. Defense gene expression in Sorghum bicolor against Macrophomina phaseolina in leaves and roots of susceptible and resistant cultivars. J. Plant Interact. 2014, 9, 315-323. [CrossRef]

25. Koike, S.T. Crown rot of strawberry caused by Macrophomina phaseolina in California. Plant Dis. 2008, 92, 1253. [CrossRef]

26. Koike, S.T.; Arias, R.S.; Hogan, C.S.; Martin, F.N.; Gordond, T.R. Status of Macrophomina phaseolina on strawberry in California and preliminary characterization of the pathogen. Int. J. Fruit Sci. 2016, 16, 148-159. [CrossRef]

27. Abed-Ashtiani, F.; Narmani, A.; Arzanlou, M. Macrophomina phaseolina associated with grapevine decline in Iran. Phytopathol. Mediterr. 2018, 57, 107-111. [CrossRef]

28. Gonzalez, V.; Tello, M.L. The endophytic mycota associated with Vitis vinifera in central Spain. Fungal Divers. 2011, 47, 29-42. [CrossRef]

29. Nouri, M.T.; Zhuang, G.; Culumber, C.M.; Trouillas, F.P. First Report of Macrophomina phaseolina Causing trunk and cordon canker disease of grapevine in the United States. Plant Dis. 2018, 103, 579. [CrossRef]

30. Sergeeva, V.; Tesoriero, L.; Spooner-Hart, R.; Nair, N. First report of Macrophomina phaseolina on olives (Olea europaea) in Australia. Australas. Plant Pathol. 2005, 34, 273-274. [CrossRef]

31. Inderbitzin, P.; Bostock, R.M.; Trouillas, F.P.; Michailides, T.J. A six locus phylogeny reveals high species diversity in Botryosphaeriaceae from California almond. Mycologia 2010, 102, 1350-1368. [CrossRef]

32. Diourte, M.; Starr, J.L.; Jeger, M.J.; Stack, J.P.; Rosenow, D.T. 1995. Charcoal rot (Macrophomina phaseolina) resistance and the effects of water stress on disease development in sorghum. Plant Pathol. 1995, 44, 196-202. [CrossRef]

33. White, T.J.; Bruns, T.; Lee, S.; Taylor, J. Amplification and direct sequencing of fungal ribosomal RNA genes for phylogenetics. In PCR Protocols: A Guide to Methods and Applications; Innis, M.A., Gelfand, D.H., Snisky, J.J., White, T.J., Eds.; Academic: San Diego, CA, USA, 1990; pp. 315-322.

34. Carbone, I.; Kohn, L.M. A method for designing primer sets for speciation studies in filamentous ascomycetes. Mycologia 1999, 3, 553-556. [CrossRef] 
35. Glass, N.L.; Donaldson, G.C. Development of primer sets designed for use with the PCR to amplify conserved genes from filamentous Ascomycetes. Appl. Environ. Microbiol. 1995, 61, 1323-1330. [CrossRef]

36. Tamura, K.; Stecher, G.; Peterson, D.; Filipski, A.; Kumar, S. MEGA6: Molecular evolutionary genetics analysis version 6.0. Mol. Biol. Evol. 2013, 30, 2725-2729. [CrossRef]

37. Maddison, W.P.; Maddison, D.R. Mesquite: A Modular System for Evolutionary Analysis. Version 3.10. 2016. Available online: http://mesquiteproject.org (accessed on 19 July 2019).

38. Swofford, D. PAUP 4: Phylogenetic Analysis Using Parsimony (*and Other Methods); Sinauer Associates: Sunderland, MA, USA, 2002.

39. Zwickl, D.J. Genetic Algorithm Approaches for the Phylogenetic Analysis of Large Biological Datasets under the Maximum Likelihood Criterion. Ph.D. Thesis, Department of Integrative Biology, University of Texas at Austin, Austin, TX, USA, 2006.

40. Chen, S.F.; Morgan, D.P.; Hasey, J.K.; Anderson, K.; Michailides, T.J. Phylogeny, morphology, distribution, and pathogenicity of Botryosphaeriaceae and Diaporthaceae from English walnut in California. Plant Dis. 2014, 98, 636-652. [CrossRef]

(C) 2020 by the authors. Licensee MDPI, Basel, Switzerland. This article is an open access article distributed under the terms and conditions of the Creative Commons Attribution (CC BY) license (http://creativecommons.org/licenses/by/4.0/). 